\title{
Plerixafor in poor mobilizers with non-Hodgkin's lymphoma: a multi-center time-motion analysis
}

\author{
Mohamad Mohty ${ }^{1} \cdot$ Nabih Azar $^{2} \cdot{\text { Christian Chabannon } \mathbb{1}^{3} \cdot \text { Steven Le Gouill }}^{4} \cdot$ Lionel Karlin $^{5} \cdot$ Lucia Farina $^{6}$. \\ Gary Milkovich $^{7} \cdot$ Helmut Ostermann $^{8} \cdot$ Bertram Glaß $^{9} \cdot$ Richard Noppeney $^{10} \cdot$ Florian Kron $^{11} \cdot$ Anna Kron $^{11}$. \\ Kai Hübel ${ }^{12}$
}

Received: 28 June 2017 / Revised: 17 September 2017 / Accepted: 5 October 2017 / Published online: 18 December 2017

(c) The Author(s) 2018. This article is published with open access

\begin{abstract}
High-dose chemotherapy alongside peripheral blood stem cell (PBSC) infusion has become the standard of care in different hematologic malignancies. The goal of PBSC mobilization is to allow collection of sufficient CD34+ cells to proceed to transplantation. The current mobilization regimen with granulocyte colony-stimulating factor (G-CSF), alone or in combination with chemotherapy, still fails in 10-25\% of patients. Plerixafor is able to rescue most of these patients from mobilization failure. In this study, we investigated the impact of plerixafor on the cost and time spent on apheresis in patients who were considered poor mobilizers, with $<20 \times 10^{6} / \mu \mathrm{l}$ peripheral CD34+ cells after mobilization but prior to apheresis. Patient hospital records from ten centers in three European countries were reviewed and compared during two time periods, namely prior and after plerixafor introduction to the market. During the plerixafor period, patients spent less time on apheresis (350 vs. $461 \mathrm{~min}$ ). Poor mobilizers given plerixafor collected more CD34+ cells during the first apheresis session, leading to a decrease in the average number of apheresis sessions needed. The total apheresis yield was unaffected. This analysis shows that the use of plerixafor lessens the time-effort associated with the management of poor mobilizers and reduces apheresis costs.
\end{abstract}

\section{Introduction}

Non-Hodgkin's lymphoma (NHL) is a heterogeneous group of malignancies, arising from aberrant B-cells, T-cells, or natural killer (NK) cells at various stages of maturity. Untreated, the prognosis for patients with relapsed NHL is

Electronic supplementary material The online version of this article (https://doi.org/10.1038/s41409-017-0033-0) contains supplementary material, which is available to authorized users.

Mohamad Mohty

mohamad.mohty@inserm.fr

1 Department of Haematology, Saint-Antoine Hospital, Paris, France

2 Department of Haematology, Pitie-Salpetriere Hospital, Paris, France

3 CBT-1409: INSERM, Aix Marseille Univ, Institut PaoliCalmettes, Marseille, France

4 Service d'Hématologie, Centre Hospitalo-Universitaire Nantes, Nantes, France

5 Centre Hospitalier Lyon-Sud, Pierre-Bénite, France

6 Hematology Department, Fondazione IRCCS Istituto Nazionale poor. However, treatment options have continuously evolved and a significant number of patients can achieve long-term remission or even cure.

In patients with relapsed or refractory NHL, autologous stem cell transplantation (ASCT) combined with high-dose chemotherapy (HDCT) is part of standard therapy. ASCT serves to overcome the bone marrow toxicity of HDCT, which increases the risk of infection and organ toxicity.

ASCT is a complex process, involving different departments and categories of healthcare professionals, the

dei Tumori, Milano, Italy

7 RJM Group, LLC, 13028 Smoketown Road, Woodbridge, VA 22192, USA

8 Department of Internal Medicine III, University of Munich, Munich, Germany

9 Department of Hematology, Oncology and Cancer Immunology, Berlin, Germany

10 Hematology, University Hospital Essen, Essen, Germany

11 Department I of Internal Medicine, Center for Integrated Oncology, University Hospital of Cologne, Cologne, Germany

12 Department of Internal Medicine, University Hospital of Cologne, Cologne, Germany 
coordination of which significantly varies from one center to another. Apheresis contributes substantially to the overall costs, which further increase in case of mobilization failure explaining the keen interest in determining mobilization procedures, which optimize costs and patient outcomes [1-4].

Nowadays, hematopoietic growth factors, such as granulocyte colony-stimulating factor (G-CSF) are used for PBSC mobilization with or without chemotherapy and the number of circulating PBSCs is monitored via CD34+ cell count. Apheresis is initiated when peak CD34+ levels are attained, typically at day 4-5 of mobilization with G-CSF only and at day 8-12 with G-CSF/chemotherapy mobilization when neutrophils recover, the latter being hampered by decreased predictability of the starting collection day. The generally accepted minimum $\mathrm{CD} 34+$ cell yield to proceed to transplantation is $\geq 2 \times 10^{6}$ cells $/ \mathrm{kg}$ [5]; however, higher yields of $4-5 \times 10^{6} \mathrm{CD} 34+$ cell $/ \mathrm{kg}$ are aimed for at many centers, since they have been associated with faster neutrophil and platelet recovery, reduced hospitalization, blood transfusions, and antibiotic therapy [6-10].

Today, 10-25\% of patients fail to obtain sufficient CD34 + cell yields to proceed to ASCT with the standard G-CSF/ chemotherapy regimen $[11,12]$.

Plerixafor, a CXCR4 antagonist, in combination with GCSF has shown to significantly increase the number of peripheral CD34+ cells as compared to G-CSF alone when used upfront in multiple myeloma (MM), NHL, and Hodgkin's lymphoma patients undergoing ASCT [13, 14]. Plerixafor may also rescue patients from mobilization failure in case of poor mobilization in response to G-CSF only [15-17]. Several cost-effectiveness studies have shown that plerixafor, when given to poor mobilizers, decreased mobilization failure rates at an acceptable increase in costs for patients with MM and NHL [13,18-20]. A direct comparison between studies is hampered because of differences in the ASCT procedure and local guidelines, health care provision, and reimbursement. While these studies lend support to current recommendations to use plerixafor in poor mobilizers, they do not address the specific consequences of plerixafor on poor mobilizers in terms of costs and time-effort spent on apheresis.

The objective of the present study was to evaluate cost and time spent on apheresis in poor mobilizers, defined as patients with a CD34+ count $\leq 20$ cells/ $\mu$ after mobilization but before the first apheresis session. Patients from two time periods, i.e. before and after the market introduction of plerixafor, were compared.

\section{Methods and patients}

This was a non-interventional study, consisting of a retrospective and prospective part, in which patients were evenly divided between two eras: (1) prior to approval of plerixafor by the European Medicines Agency (July 2009) and (2) after approval of plerixafor. The study was conducted at ten European centers where plerixafor was included as a treatment option for patients eligible for ASCT from July 1, 2010. The study protocol was approved by the central and local ethics committees according to national legislations. No informed consent was required for this retrospective study. This study was registered with ClinicalTrials.gov, number NCT02287012.

\section{Inclusion criteria}

Patients were eligible if 18 years or older with a diagnosis of NHL and candidates for ASCT, and if they failed to achieve a target CD34+ count $>20$ cells/ $\mu$ l before or on the first day of apheresis. Patients with a history of previous ASCT and/or a diagnosis other than NHL were excluded to obtain a homogeneous patient population.

\section{Data collection and extraction}

For the retrospective part, patient records were analyzed from June 1, 2007 to June 1, 2009 for the pre-plerixafor era and from July 1, 2010 to July 1, 2012 for the plerixafor era. At each center patients fulfilling the inclusion criteria were sequentially included, starting from June 1, 2007, until a number of 20 patients was reached or all records were exhausted.

Each plerixafor era patient was matched on a 1:1 basis to a pre-plerixafor era patient, based on CD34+ target levels. Enrollment continued until a single CD34+ target level match was found for each plerixafor era patient or the pool of preplerixafor patients was exhausted. If no CD34+ target level match was found, the plerixafor patient was excluded.

The following data were extracted: baseline characteristics, diagnosis (NHL subtype), number of mobilization visits and mobilization agents, adverse events, number and duration of apheresis sessions, total CD34+ cells collected and transplanted, transplantation outcome, and costs associated with mobilization, apheresis, and cryopreservation.

Costs were obtained through interviews with local hospital administration at three centers in France and Germany. Information about resource use and costs associated with each step in the procedure and with each patient was collected, including the following items: (1) Clinical Chemistry costs prior to apheresis for CD34 levels, (2) day hospital stay for apheresis (3-6h), (3) fixed costs for apheresis including medical supplies, solutes, harvest Kit, and overhead, (4) manipulation, cell engineering, materials costs, personnel costs, and storage for one bag of collected stem cells, (5) thawing costs for one bag of stem cells infused, including medical supplies, equipment amortization, personnel costs (Supplementary information [SI] Table 1). The 
Table 1 Baseline characteristics

\begin{tabular}{l}
$\frac{\text { Pre-plerixafor era }}{(n=124)} \frac{\text { Plerixafor era }}{(n=134)}$ \\
\hline
\end{tabular}

Age in years

Mean (SD)

Median (Q1-Q3) 57

Range (min-max)

$(46-63)$
$(22-73)$

56

(11)

Height in $\mathrm{cm}$

\begin{tabular}{|c|c|c|c|c|}
\hline Mean (SD) & 171 & (10) & 171 & (10) \\
\hline Median (Q1-Q3) & 172 & $(165-178)$ & 171 & (164-178) \\
\hline
\end{tabular}

Range (min-max)

(150-204)

(143-194) 0.96 (a)

Weight in $\mathrm{kg}$

$\begin{array}{llllll}\text { Mean (SD) } & 73 & (16) & 73 & (15) & \\ \text { Median (Q1-Q3) } & 72 & (62-84) & 73 & (62-82) & \\ \text { Range (min-max) } & & (43-140) & & (47-118) & 0.90 \text { (a) }\end{array}$

Months since diagnosis

Median (Q1-Q3) 11

Range (min-max)

27

(46)

ender

$$
\begin{array}{ll}
\text { Female }-n(\%) & 49 \\
\text { Male- } n(\%) & 75
\end{array}
$$

Nation

$\begin{array}{ll}\text { France- } n(\%) & 59 \\ \text { Germany- } n(\%) & 39 \\ \text { Italy- } n(\%) & 26\end{array}$

NHL subtype

$\begin{array}{llllll}\text { Follicular- } n(\%) & 27 & (22 \%) & 32 & (24 \%) & \\ \text { Diffuse- } n(\%) & 49 & (40 \%) & 54 & (40 \%) & \\ \text { Mantle- } n(\%) & 17 & (14 \%) & 18 & (13 \%) & \\ \text { Other- } n(\%)^{\mathrm{a}} & 31 & (25 \%) & 30 & (22 \%) & 0.96(\mathrm{c})\end{array}$

Disease stage at diagnosis

$\begin{array}{ll}\text { I-n (\%) } & 6 \\ \text { II-n }(\%) & 10 \\ \text { III-n }(\%) & 17 \\ \text { IV—n (\%) } & 85 \\ \text { Unknown-n (\%) } & 6\end{array}$

\begin{tabular}{|c|c|c|c|c|c|}
\hline Rituximab- $n(\%)$ & 6 & $(5 \%)$ & 7 & $(5 \%)$ & 0.89 (c) \\
\hline $\begin{array}{l}\text { DHAP/R-DHAP } \\
-n(\%)\end{array}$ & 40 & $(32 \%)$ & 29 & $(22 \%)$ & 0.05 (c) \\
\hline $\mathrm{ESHAP}-n(\%)$ & 7 & $(6 \%)$ & 2 & $(1 \%)$ & 0.09 (d) \\
\hline $\mathrm{R}-\mathrm{CHOP}-n(\%)$ & 16 & $(13 \%)$ & 15 & $(11 \%)$ & 0.67 (c) \\
\hline $\begin{array}{l}\text { Methotrexate- } \\
n(\%)\end{array}$ & 3 & $(2 \%)$ & 9 & $(7 \%)$ & $0.10(\mathrm{c})$ \\
\hline $\begin{array}{l}\mathrm{R}-\mathrm{ACVBP}- \\
n(\%)\end{array}$ & 3 & $(2 \%)$ & 3 & $(2 \%)$ & $1.00(\mathrm{~d})$ \\
\hline Other & 60 & $(48 \%)$ & 86 & $(64 \%)$ & $0.01(\mathrm{c})$ \\
\hline
\end{tabular}

Chemotherapy for mobilization ${ }^{\mathrm{b}}$

Chemotherapy courses ${ }^{c}$
Table 1 (continued)

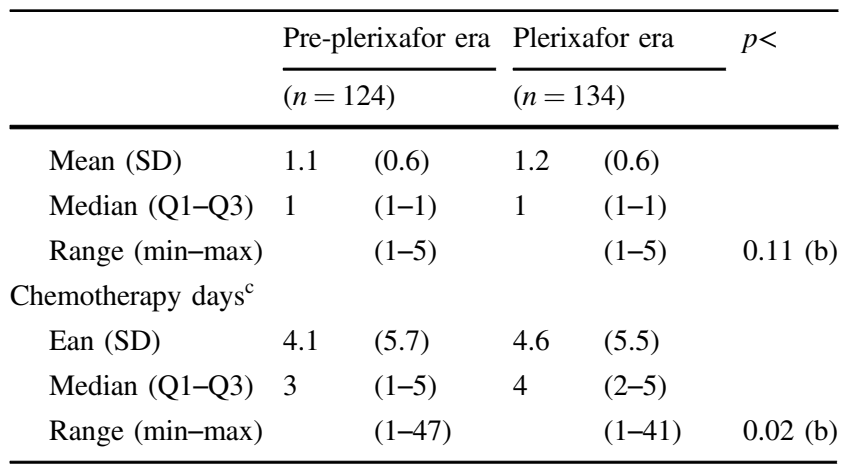

(a) Student's $t$-test, (b) Wilcoxon rank sum, and (c) Chi square (d) Fisher's Exact

a NHL subtypes included in "other" are provided in SI Table 2

b Only chemotherapy regimens given up to 30 days prior to mobilization were considered as part of the mobilization regimen. Each patient received at least 1 chemotherapy regimen. Patients could receive more than 1 chemotherapy regimen

c Chemotherapy courses corresponds to the number of cycles of chemotherapy received prior to apheresis; chemotherapy days corresponds to the number of days chemotherapy was administered

costs for apheresis at the single Italian site was imputed from a previous micro-costing analysis using data from 25 Italian sites [1].

All patient data were transcribed onto the case report form in an anonymous fashion according to current requirements (no patient initials and no connection table between patient number and patient file).

For the prospective part, patients were enrolled if they were scheduled for peripheral blood stem mobilization in the apheresis area of the hospital. Time spent on apheresis was assessed and validated using time-motion techniques on these prospectively enrolled patients as described below.

\section{Time-motion of apheresis events}

Apheresis practice-related activities were identified to be consistent with each hospital's procedures. The chart of enrolled patients was reviewed by study-specific personnel trained in standard time-motion technique. The time spent for clinical assessment, medical record entry, management of supplies, apheresis, and other procedures, was recorded on the case report form by the time-motion observer. Time spent on apheresis from retrospective records was validated using time-motion observation on prospectively enrolled patients. The primary diagnosis, adverse events and procedures to manage adverse events, apheresis duration and date and time of the apheresis session were recorded. Regarding the apheresis procedure, the time when the patient presented to the apheresis department, time when the apheresis 
session initiated and ended, the total apheresis time, occurrence of AEs and the treatment of those were noted.

\section{Statistical analysis}

The primary endpoint of this study was time and effort to mobilize patients for ASCT, using two main variables: mean time to perform apheresis and cost per patient inferred to the hospital.

Secondary endpoints included number of visits for mobilization purposes and number of days receiving mobilizing agents, number and duration (hours) of apheresis sessions, time from apheresis to transplant, transplant outcome, attainment of CD34+ cell target, days until the target was met, and adverse events during mobilization.

The study sample size was determined based on results regarding the number of days needed for mobilization and collection during the period prior to and after the introduction of plerixafor as reported by Micallef et al. [21]. Based on results reported from that study, we estimated a sample size of 100 patients per time period would provide $88 \%$ power to detect a 1.4 days difference, assuming use of a one-tailed test with alpha $=0.05$.

Exploratory and descriptive analysis was carried out for the number of minutes to perform apheresis per patient at a given hospital, and the cost of apheresis per patient in terms of micro-costing per site.

For categorical data, differences between eras were evaluated using McNemar's test for matched pairs. For continuous data, difference scores were calculated by subtracting the value for each plerixafor era patient from the value of his/her matched control. If the difference score was normally distributed, the statistical significance was assessed using the paired $t$-test. If the data were not normally distributed, the Wilcoxon signed rank test was used instead. Normality of each distribution was determined using Kolmogorov-Smirnov test.

\section{Results}

During the pre-plerixafor era 124 NHL patients were identified as poor mobilizers who underwent at least one apheresis session. During the plerixafor era, 134 patients with $\mathrm{CD} 34+$ cell count $\leq 20$ cells $/ \mu \mathrm{l}$ and who underwent at least one apheresis session were identified.

The demographic characteristics of the two patient groups were not significantly different. Disease subtypes were similarly distributed during the pre-plerixafor and plerixafor era with diffuse large B-cell lymphoma being the most common subtype (40\%), followed by follicular lymphoma (22-24\%) and mantle cell lymphoma (13-14\%) (Table 1, SI Tables 2, 3a, 3b).
There were few differences between the two treatment eras in terms of mobilization regimens besides the use of plerixafor (Table 1). More patients in the pre-plerixafor era received DHAP as chemotherapy ( 9 vs. $2 \% ; p=0.02$ ). Patients in the plerixafor era had more days of chemotherapy (4.6 vs $4.1 ; p=0.02)$. The mean number of G-CSF doses was 10.5 and 10.3 in the pre-plerixafor and plerixafor era, respectively, while the mean number of plerixafor doses was 1.5 .

The initial CD34+ cell count, i.e. the count before the first apheresis session, was significantly higher in patients from the pre-plerixafor era compared to patients from the plerixafor era $(12.7$ vs. 8.7 cells $/ \mu l ; p<0.001)$. Despite the lower $\mathrm{CD} 34+$ cell count in the plerixafor era, apheresis outcome measures were in favor of the plerixafor era patients: they underwent fewer apheresis sessions $(p<$ $0.001)$, spent less time on apheresis $(p<0.001)$, which led to a reduction in costs associated with apheresis from $€ 6212$ to $€ 4457$ ( $p<0.001)$ (Table 2). The CD34+ cell yield was significantly higher after the first apheresis session for patients in the plerixafor era $(p<0.001)$, but the cumulated number of collected CD34+ cells was similar between the two groups $(p=0.43)$. Also, a higher proportion of patients reached $2 \times 10^{6}$ cells $/ \mathrm{kg}$ in the plerixafor era as compared to the pre-plerixafor era ( 91 vs. $83 \%$ in the plerixafor and preplerixafor era, respectively; $p=0.06$ ). Time-motion analysis for prospectively enrolled patients yielded similar results in terms of time spent on apheresis as those obtained from the retrospective data. An additional $30 \mathrm{~min}$ was identified as spent on set-up and cleaning of the apheresis equipment (SI Table 4).

Given the difference in initial peripheral blood (PB) $\mathrm{CD} 34+$ cell count, a subgroup analysis was carried out in patients with initial CD34+ cell count $\leq 10$ cells $/ \mu l$ and those with CD34+ cell count $>10$ cells/ $\mu$.

Forty-one patients in the pre-plerixafor and 88 patients in the plerixafor era were identified with initial CD34+ cell count $\leq 10$ cells $/ \mu$ l. Among these patients, apheresis outcomes were in favor of the plerixafor era, including total CD34+ cell yield $(p<0.02)$ (Table 3$)$.

In patients with initial PB CD34+ numbers $>10 / \mu 1(83$ and 46 patients in the pre-plerixafor and plerixafor era, respectively), apheresis outcomes were also in favor of the plerixafor era; however, the total CD34+ cell yield was not significantly different between the two treatment groups (SI Table 5).

Matched pair analysis was carried out to reduce the bias due to possible confounding factors by matching plerixafor and pre-plerixafor patients on center and initial CD34+ cell counts. Results of this analysis are in agreement with the analysis on the full population (SI Tables 6-9).

At a country level, some differences were observed (Fig. 1; Tables SI 10-12). The French data mimics the 
Table 2 Apheresis activities

\begin{tabular}{|c|c|c|c|c|c|}
\hline & \multicolumn{2}{|c|}{$\begin{array}{l}\text { Pre-plerixafor era }(n= \\
124)\end{array}$} & \multicolumn{2}{|c|}{ Plerixafor era $(n=134)$} & $p<$ \\
\hline \multicolumn{6}{|c|}{ Initial peripheral CD34+ count (cells/ $\mu \mathrm{l})$} \\
\hline Mean (SD) & 12.7 & $(5.4)$ & 8.7 & $(4.9)$ & \\
\hline Median (Q1-Q3) & 14.0 & $(9.8-17.0)$ & 8.0 & $(5.0-12.0)$ & \\
\hline Range (min-max) & & $(0.0-20.0)$ & & $(1.0-20.0)$ & $0.001(b)$ \\
\hline \multicolumn{6}{|c|}{ Number of apheresis sessions } \\
\hline Mean (SD) & 2.2 & $(0.9)$ & 1.6 & $(0.7)$ & \\
\hline Median (Q1-Q3) & 2.0 & $(2.0-3.0)$ & 1.0 & $(1.0-2.0)$ & \\
\hline Range (min-max) & & $(1.0-5.0)$ & & $(1.0-4.0)$ & $0.001(\mathrm{~b})$ \\
\hline \multicolumn{6}{|c|}{ Total apheresis blood volume (1) } \\
\hline Mean (SD) & 25.3 & $(12.3)$ & 18.6 & $(10.3)$ & \\
\hline Median (Q1-Q3) & 23.6 & $(15.3-32.1)$ & 16.2 & $(11.5-23.3)$ & \\
\hline Range (min-max) & & $(3.4-68.9)$ & & $(4.1-67.0)$ & $0.001(b)$ \\
\hline \multicolumn{6}{|c|}{ Total minutes of apheresis } \\
\hline Mean (SD) & 463 & (216) & 350 & $(150)$ & \\
\hline Median (Q1-Q3) & 428 & $(290-565)$ & 298 & $(229-474)$ & \\
\hline Range (min-max) & & $(135-1273)$ & & $(125-880)$ & $0.001(b)$ \\
\hline \multicolumn{6}{|c|}{ Estimated apheresis cost in $€$} \\
\hline Mean (SD) & 6212 & $(2674)$ & 4457 & $(1860)$ & \\
\hline Median (Q1-Q3) & 5688 & $(5688-8532)$ & 2844 & $(2844-5688)$ & \\
\hline Range (min-max) & & $(2844-14220)$ & & $(2844-11376)$ & $0.001(b)$ \\
\hline \multicolumn{6}{|c|}{ CD34 + cells, total $\left(\times 10^{6}\right.$ cells $\left./ \mathrm{kg}\right)$} \\
\hline Mean (SD) & 4.3 & $(2.8)$ & 4.4 & (2.6) & \\
\hline Median (Q1-Q3) & 3.8 & $(2.3-5.2)$ & 3.7 & $(2.9-5.3)$ & \\
\hline Range (min-max) & & $(0.4-12.2)$ & & $(0.8-13.8)$ & $0.43(b)$ \\
\hline \multicolumn{6}{|c|}{ CD34+ cells, first apheresis $\left(\times 10^{6}\right.$ cells $\left./ \mathrm{kg}\right)$} \\
\hline Mean (SD) & 2.2 & $(2.3)$ & 3.2 & $(2.2)$ & \\
\hline Median (Q1-Q3) & 1.4 & $(1.0-2.3)$ & 2.5 & $(1.7-3.8)$ & \\
\hline Range (min-max) & & $(0.4-12.2)$ & & $(0.5-13.8)$ & $0.001(b)$ \\
\hline
\end{tabular}

(b) Wilcoxon Rank Sum

overall results, while reductions in time and effort were more modest for the German sites (Table SI 11). At the single Italian site, introduction of plerixafor reduced the number of apheresis sessions and time spent on apheresis and the CD34+ cell yield was significantly higher in the plerixafor era (Table SI 12).

There was no significant difference in the percentage of patients proceeding to stem cell transplantation before and after introduction of plerixafor (76 vs. $84 \%, p=0.09$ ). Platelet engraftment was observed in 81 and $76 \%$ of preplerixafor and plerixafor patients, respectively, while neutrophil engraftment was reported in 93 and $91 \%$ of preplerixafor and plerixafor patients, respectively (Table SI 13).

A higher proportion of patients in the plerixafor era received transfusions with platelets ( 72 vs. $60 \% ; p=0.04$ ) and red blood cells (62 vs. $47 \% ; p=0.01)$ and the average number of platelet and red blood cell transfusions was higher in patients treated during the plerixafor era
(Table SI 14). Adverse events were reported with the same frequency in the two treatment eras, with the most common adverse events belonging to blood and lymphatic system disorders (Table SI 15).

\section{Discussion}

Stem cell mobilization is a time-consuming process for hospitals requiring specific apheresis equipment and the presence of trained staff throughout the entire procedure. Failure to achieve sufficient CD34+ cell yield through apheresis not only diminishes the chances to proceed to transplantation, but also increases the need for additional health care resources and leads to a poorer prognosis [3, 12, 22].

Plerixafor, a CXCR4 inhibitor increases the number of circulating PBSCs and decreases the mobilization failure rate. In addition, plerixafor was shown to increase the 
Table 3 Apheresis outcomes for patients with initial CD34+ count $\leq 10 \times 10^{6} \mathrm{cells} / \mu \mathrm{l}$

\begin{tabular}{|c|c|c|c|c|c|}
\hline & \multicolumn{2}{|c|}{ Pre-plerixafor era $(n=41)$} & \multicolumn{2}{|c|}{ Plerixafor era $(n=88)$} & \multirow[t]{2}{*}{$p<$} \\
\hline \multicolumn{5}{|c|}{ Initial peripheral CD34+ (cells/ $\mu \mathrm{l})$} & \\
\hline Mean (SD) & 6.5 & $(3.3)$ & 5.7 & $(2.7)$ & \\
\hline Median (Q1-Q3) & 7.7 & $(4.0-9.7)$ & 6.0 & $(3.3-8.0)$ & \\
\hline Range (min-max) & & $(0.0-10.0)$ & & $(1.0-10.0)$ & $0.07(b)$ \\
\hline \multicolumn{6}{|c|}{ Number of apheresis sessions } \\
\hline Mean (SD) & 2.2 & $(0.9)$ & 1.6 & $(0.6)$ & \\
\hline Median (Q1-Q3) & 2.0 & $(2.0-2.0)$ & 2.0 & $(1.0-2.0)$ & \\
\hline Range (min-max) & & $(1.0-5.0)$ & & $(1.0-4.0)$ & $0.001(b)$ \\
\hline \multicolumn{6}{|c|}{ Total apheresis blood volume (l) } \\
\hline Mean (SD) & 27.1 & $(13.8)$ & 19.6 & $(10.7)$ & \\
\hline Median (Q1-Q3) & 23.9 & $(19.3-33.7)$ & 17.6 & $(11.6-24.0)$ & \\
\hline Range (min-max) & & $(4.5-68.9)$ & & $(4.1-67.0)$ & $0.001(b)$ \\
\hline \multicolumn{6}{|c|}{ Total minutes of apheresis } \\
\hline Mean (SD) & 457 & (204) & 361 & $(151)$ & \\
\hline Median (Q1-Q3) & 430 & $(290-550)$ & 306 & $(239-484)$ & \\
\hline Range (min-max) & & $(180-1065)$ & & $(150-732)$ & $0.01(b)$ \\
\hline \multicolumn{6}{|c|}{ Estimated apheresis cost in $€$} \\
\hline Mean (SD) & 6174 & $(2455)$ & 4622 & $(1845)$ & \\
\hline Median (Q1-Q3) & 5688 & $(5688-5688)$ & 5688 & $(2844-5688)$ & \\
\hline Range (min-max) & & $(2844-14,220)$ & & $(2844-11,376)$ & $0.001(b)$ \\
\hline \multicolumn{6}{|c|}{$\mathrm{CD} 34+$ cells, total $\left(\times 10^{6}\right.$ cells $\left./ \mathrm{kg}\right)$} \\
\hline Mean (SD) & 3.2 & $(1.9)$ & 4.2 & $(2.2)$ & \\
\hline Median (Q1-Q3) & 3.1 & $(1.4-4.5)$ & 3.7 & $(2.9-4.8)$ & \\
\hline Range (min-max) & & $(0.4-8.0)$ & & $(0.8-12.9)$ & $0.02(b)$ \\
\hline \multicolumn{6}{|c|}{ CD34+ cells, first apheresis $\left(\times 10^{6}\right.$ cells $\left./ \mathrm{kg}\right)$} \\
\hline Mean (SD) & 1.5 & $(1.4)$ & 2.7 & $(1.4)$ & \\
\hline Median (Q1-Q3) & 1.2 & $(0.7-1.7)$ & 2.5 & $(1.7-3.6)$ & \\
\hline Range (min-max) & & $(0.4-8.0)$ & & $(0.6-8.1)$ & $0.001(b)$ \\
\hline
\end{tabular}

(b) Wilcoxon rank sum apheresis yield and reduce the number of apheresis sessions needed to proceed to transplantation $[13,23]$.

Previous studies did not specifically evaluate the impact of plerixafor on apheresis in NHL patients mobilizing poorly, i.e. initial peripheral CD34+ cell count $\leq 20$ cells $/ \mu 1$. In our study, time spent on apheresis and costs related to apheresis (excluding mobilization) were analyzed and compared in poor mobilizers from two time periods: before the introduction of plerixafor on the market (pre-plerixafor era) and after its introduction (plerixafor era). The two groups were very similar in terms of age, gender, weight, time since diagnosis, NHL subtype and type of mobilization regimen, including chemotherapy received. The only significant difference was the average initial CD34+ cell count, which was lower in the plerixafor era (8.7 vs. 12.7 cells/ $\mu \mathrm{l})$. A low initial CD34+ cell count was shown to correlate with poor apheresis outcome [12], which explains the reluctance to proceed to apheresis in case of very low initial PBSC $(\leq 10$ cells $/ \mu \mathrm{l})$ in the pre-plerixafor era. In that era, only 41 out of 124 patients (33\%) with initial CD34+ cell count $\leq 10$ cells/ $\mu$ l who underwent at least one apheresis session were identified, while in the plerixafor era 88 out of the selected 134 patients $(66 \%)$ had a CD34+ cell count in that range.

Regardless of the initial CD34+ cell count, our study revealed that plerixafor led to a significant decrease in time spent on apheresis. Concomitantly, costs associated with apheresis decreased and this reduction may partially compensate the costs of plerixafor.

Whether plerixafor is cost-effective depends on the selected perspective, as well as on fees and procedures, specific to each institution [21, 24-26]. Studies adopting a wider perspective which captures additional costs incurred to the hospital due to mobilization failure (e.g. delay in treatment, disruption of patient flow, inability to proceed to transplantation) have shown that plerixafor improves the 

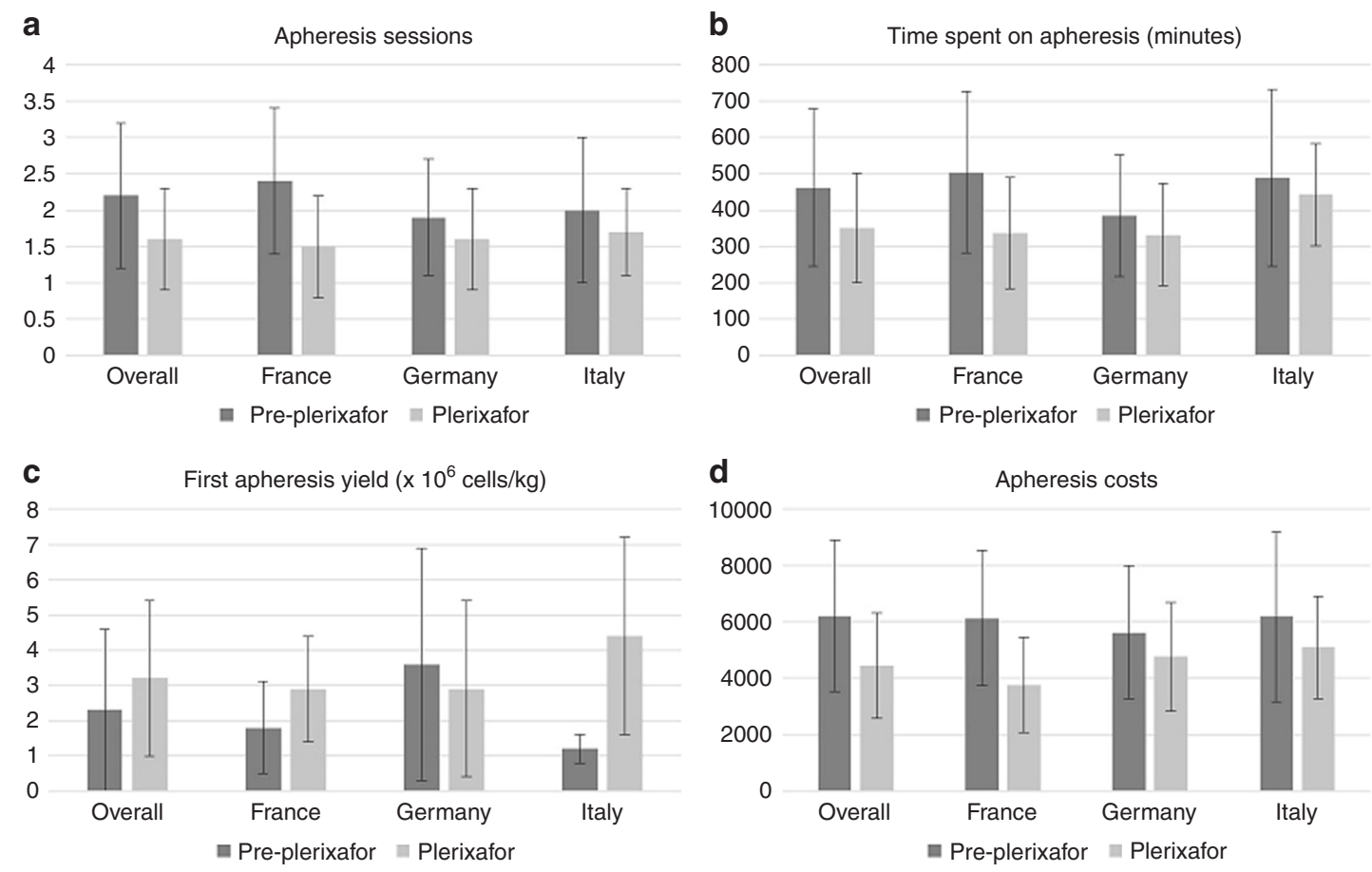

Fig. 1 Selected outcomes by country; mean numbers are shown for the pre-plerixafor and plerixafor era and standard deviations are depicted as vertical lines. a Mean number of apheresis sessions. b Mean number

of minutes spent on apheresis. c Mean number of first apheresis yield. d Mean apheresis costs

use of apheresis capacities and may even be cost-saving [18, $22,27]$. Here, a narrow perspective was selected on purpose to decrease the institution-specific variations and to increase the generalizability of our results. A decrease in apheresis costs between $€ 866$ and $€ 2385$ was observed in all countries participating in this study upon introduction of plerixafor. Analyses of hospital charges at different study sites resulted in an average cost per apheresis session of $€ 2515$ for France, $€ 2928$ for Germany, and $€ 3089$ for Italy (Table SI 1). The average apheresis cost across the three nations was $€ 2844$ corresponding to $\$ 3100$, similar to the cost per apheresis session of $\$ 3200$ found by a recent pharmacoeconomic analysis carried out at a single US center [28].

In terms of apheresis outcome, plerixafor boosted the CD34+ yield after the first apheresis session: the average yield increased from $2.3 \times 10^{6} \mathrm{CD} 34+$ cells $/ \mathrm{kg}$ to $3.2 \times 10^{6}$ $\mathrm{CD} 34+$ cells $/ \mathrm{kg}$. The total yield was not significantly different between the two groups; however, the same yield was achieved with fewer apheresis sessions despite lower initial CD34+ cell count.

In patients with very low initial CD34+ cell count $(\leq 10$ cells $/ \mu \mathrm{l})$, plerixafor increased the total CD34+ cell yield significantly from $3.2 \times 10^{6} \mathrm{CD} 34+$ cells $/ \mathrm{kg}$ to $4.2 \times 10^{6}$ $\mathrm{CD} 34+$ cells $/ \mathrm{kg}$. A similar finding was reported by Nademanee et al. in a post-hoc analysis of a randomized clinical trial in MM patients [23]. The authors stratified patients

according to their pre-apheresis peripheral CD34+ cell count and found that plerixafor had the most marked effect on apheresis outcome in patients with an initial PB CD34+ count $\leq 10$ cells $/ \mu$ l.

In our study, the number of patients reaching the minimum target of $2 \times 10^{6} \mathrm{CD} 34+$ cells $/ \mathrm{kg}$ was $83 \%$ in the preplerixafor era and $91 \%$ in the plerixafor era $(p=0.06)$. When only considering those with an initial CD34+ cell count of $\leq 10 / \mu 1,69 \%$ of patients in the pre-plerixafor era and $93 \%$ of patients in the plerixafor era obtained at least a $2 \times 10^{6} \mathrm{CD} 34+$ cells $/ \mathrm{kg}$ collection yield $(p=0.002)$.

The proportion of patients proceeding to transplantation and reporting successful engraftment did not significantly differ between treatment eras. This finding is in agreement with other studies which showed that plerixafor improved mobilization and collection of stem cells but did not affect the success rate of transplantation and/or platelet and neutrophil engraftment [29]. Therefore, the benefit of plerixafor mostly relies on increasing the number of patients reaching minimum and target CD34+ cell yields in fewer apheresis sessions.

This study has several limitations: we only analyzed cost and effort associated with apheresis. Costs associated with hospitalization, mobilization or remobilization, transplantation, platelet and RBC infusions and other posttransplantation care were not considered. Several reports have highlighted that processes may vary considerably 
between countries and institutions $[1,19,30]$. Therefore, in this study only the impact of plerixafor on apheresis was analyzed, which was thought to be more comparable between institutions. Indeed, a significant reduction in time spent on apheresis and costs related to apheresis was found for all participating countries. Finally, methodological and technical aspects of apheresis might evolve over time; however, we found that during the study period procedures and equipment didn't significantly change at the participating centers.

Nevertheless, some country and/or institution-specific differences persisted: In Italy, cytosine-arabinoside was often applied as part of a high-dose sequential chemotherapy, since this regimen showed to be effective in poor mobilizers [31]. The combination of high dose cytosine-arabinoside with plerixafor may explain the fivefold increase in CD34+ cell yields from the first apheresis session in Italian patients compared to the other countries [31]. However, this regimen is no longer recommended due to severe adverse effects. Not all sites use plerixafor preemptively in all patients with CD34+ levels $\leq 20$ cells/ $\mu \mathrm{l}$. As recommended by the European Society for Blood and Marrow Transplantation (EBMT), patients with CD34 + levels $\leq 10$ cells $/ \mu$ should receive plerixafor preemptively, while a dynamic approach based on patient characteristics, disease, and treatment history is recommended in those patients with CD34+ levels between 10 and 20 cells/ $\mu 1$ [5]. Hence, some patients may proceed to the first apheresis session and receive plerixafor only if the initial yield is insufficient and this might impact first apheresis yield.

In conclusion, plerixafor significantly reduces the average number of apheresis sessions per patient, and the average time spent on apheresis in patients with initial CD34+ cell count $\leq 20$ cells/ $\mu$ l. This leads to a reduction in apheresis costs, reproducible at different institutions, which partially offsets the costs of plerixafor.

Acknowledgements The study and medical writing, provided by Katrin Spiegel, was supported by Sanofi-Genzyme. We thank Meghan Gallagher for reading the manuscript and providing critical comments. We thank Jake Jacobs for providing statistical support.

\section{Compliance with ethical standards}

Conflict of interest MM received research support, honorarium and hospitality from SANOFI SA NA received honorarium, consultancies to sponsoring organizations and hospitality from SANOFI SA CC received research support, honorarium and hospitality from SANOFI SA and Honorarium from Terumo BCT. L.K. received traveling and accommodation support from SANOFI for ASH meeting 2015. HO received research support from SANOFI SA BG received honoraria and research funding from Sanofi and Amgen. KH received honorarium and hospitality from SANOFI SA The authors have no commercial, proprietary or financial interest in the products or companies described in this article.
Open Access This article is licensed under a Creative Commons Attribution-NonCommercial-NoDerivatives 4.0 International License, which permits any non-commercial use, sharing, distribution and reproduction in any medium or format, as long as you give appropriate credit to the original author(s) and the source, and provide a link to the Creative Commons license. You do not have permission under this license to share adapted material derived from this article or parts of it. The images or other third party material in this article are included in the article's Creative Commons license, unless indicated otherwise in a credit line to the material. If material is not included in the article's Creative Commons license and your intended use is not permitted by statutory regulation or exceeds the permitted use, you will need to obtain permission directly from the copyright holder. To view a copy of this license, http://creativecommons.org/licenses/by-nc-nd/4.0/.

\section{References}

1. Pierelli L, Berto P, Accorsi P, Milone G, Lopatriello S, Aiello A, et al. The costs of mobilisation and collection of peripheral blood stem cells in multiple myeloma and lymphoma in an European country: Results from The Gruppo Italiano Trapianto Midollo Osseo (GITMO) and Società Italiana di Emaferesi e Manipolazione Cellulare. Transfus Apher Sci. 2013;49:615-22.

2. Blommestein HM, Verelst SGR, Huijgens PC, Blijlevens NMA, Cornelissen JJ, Uyl-De Groot CA. Real-world costs of autologous and allogeneic stem cell transplantations for haematological diseases: a multicentre study. Ann Hematol. 2012;91:1945-52.

3. Gertz MA, Wolf RC, Micallef INM, Gastineau Da. Clinical impact and resource utilization after stem cell mobilization failure in patients with multiple myeloma and lymphoma. Bone Marrow Transpl. 2010;45:1396-403.

4. Chabannon C, Le Corroller A-G, Viret D, Eillen C, Faucher C, Moatti J-P, et al. Cost-effectiveness of repeated aphereses in poor mobilizers undergoing high-dose chemotherapy and autologous hematopoietic cell transplantation [4]. Leukemia 2003;17:811-3.

5. Mohty M, Hübel K, Kröger N, Aljurf M, Apperley J, Basak GW, et al. Autologous haematopoietic stem cell mobilisation in multiple myeloma and lymphoma patients: a position statement from the European Group for Blood and Marrow Transplantation. Bone Marrow Transpl. 2014;49:865-72.

6. Stiff PJ, Micallef I, Nademanee AP, Stadtmauer EA, Maziarz RT, Bolwell BJ, et al. Transplanted CD34+ cell dose is associated with long-term platelet count recovery following autologous peripheral blood stem cell transplant in patients with non-Hodgkin lymphoma or multiple myeloma. Biol Blood Marrow Transpl. 2011;17:1146-53.

7. Gunn N, Damon L, Varosy P, Navarro W, Martin T, Ries C, et al. High CD34+ cell dose promotes faster platelet recovery after autologous stem cell transplantation for acute myeloid leukemia. Biol Blood Marrow Transpl. 2003;9:643-8.

8. Giralt S, Costa L, Schriber J, Dipersio J, Maziarz R, McCarty J, et al. Optimizing autologous stem cell mobilization strategies to improve patient outcomes: consensus guidelines and recommendations. Biol Blood Marrow Transpl. 2014;20:295-308.

9. Schulman KA, Birch R, Zhen B, Pania N, Weaver CH. Effect of $\mathrm{CD} 34(+)$ cell dose on resource utilization in patients after highdose chemotherapy with peripheral-blood stem-cell support. J Clin Oncol. 1999;17:1227-33.

10. Wallington-Beddoe CT, Gottlieb DJ, Garvin F, Antonenas V, Sartor MM. Failure to achieve a threshold bose of CD34+ CD110 + progenitor cells in the graft predicts delayed platelet engraftment after autologous stem cell transplantation for multiple myeloma. Biol Blood Marrow Transpl. 2009;15:1386-93.

11. Pavone V, Gaudio F, Console G, Vitolo U, Iacopino P, Guarini A, et al. Poor mobilization is an independent prognostic factor in 
patients with malignant lymphomas treated by peripheral blood stem cell transplantation. Bone Marrow Transplant. 2006;37:719-24.

12. Pusic I, Jiang SY, Landua S, Uy GL, Rettig MP, Cashen AF, et al. Impact of mobilization and remobilization strategies on achieving sufficient stem cell yields for autologous transplantation. Biol Blood Marrow Transpl. 2008;14:1045-56.

13. Micallef IN, Stiff PJ, DiPersio JF, Maziarz RT, McCarty JM, Bridger $\mathrm{G}$, et al. Successful stem cell remobilization using plerixafor (mozobil) plus granulocyte colony-stimulating factor in patients with non-Hodgkin lymphoma: results from the plerixafor NHL phase 3 study rescue protocol. Biol Blood Marrow Transpl. 2009; 15:1578-86.

14. DiPersio JF, Micallef IN, Stiff PJ, Bolwell BJ, Maziarz RT, Jacobsen E, et al. Phase III prospective randomized double-blind placebo-controlled trial of plerixafor plus granulocyte colonystimulating factor compared with placebo plus granulocyte colony-stimulating factor for autologous stem-cell mobilization and transplantation for patients with non-Hodgkin's lymphoma. J Clin Oncol. 2009;27:4767-73.

15. Calandra G, McCarty J, McGuirk J, Tricot G, Crocker S, Badel K, et al. AMD3100 plus G-CSF can successfully mobilize CD34+ cells from non-Hodgkin's lymphoma, Hodgkin's disease and multiple myeloma patients previously failing mobilization with chemotherapy and/or cytokine treatment: compassionate use data. Bone Marrow Transpl. 2008;41:331-8.

16. Duarte RF, Shaw BE, Marín P, Kottaridis P, Ortiz M, Morante C, et al. Plerixafor plus granulocyte CSF can mobilize hematopoietic stem cells from multiple myeloma and lymphoma patients failing previous mobilization attempts: EU compassionate use data. Bone Marrow Transpl. 2011;46:52-8.

17. Chabannon C, Bijou F, Miclea JM, Milpied N, Grouin JM, Mohty M. A nationwide survey of the use of plerixafor in patients with lymphoid malignancies who mobilize poorly demonstrates the predominant use of the "on-demand" scheme of administration at French autologous hematopoietic stem cell transplant programs. Transfusion. 2015;55:2149-57.

18. Azar N, Ouzegdouh M, Choquet S, Leblond V. Impact of Plerixafor (Mozobil) on hospital efficiency: a single center experience. J Clin Apher. 2017;Apr 28(Epub ahead of print).

19. Meehan KR, Areman EM, Ericson SG, Matias C, Seifeldin R, Schulman K. Mobilization, collection, and processing of autologous peripheral blood stem cells: development of a clinical process with associated costs. J Hematother Stem Cell Res. 2000;9:767-71.

20. Fagnoni P, Milpied N, Limat S, Deconinck E, Nerich V, Foussard C, et al. Cost effectiveness of high-dose chemotherapy with autologous stem cell support as initial treatment of aggressive non-Hodgkin's lymphoma. Pharmacoeconomics. 2009;27:55-68.
21. Micallef INM, Sinha S, Gastineau DA, Wolf R, Inwards DJ, Gertz MA, et al. Cost-effectiveness analysis of a risk-adapted algorithm of plerixafor use for autologous peripheral blood stem cell mobilization. Biol Blood Marrow Transpl. 2012;19:87-93.

22. Shaughnessy P, Chao N, Shapiro J, Walters K, McCarty J, Abhyankar S, et al. Pharmacoeconomics of hematopoietic stem cell mobilization: an overview of current evidence and gaps in the literature. Biol Blood Marrow Transpl. 2013;19:1301-9.

23. Nademanee AP, DiPersio JF, Maziarz RT, Stadtmauer EA, Micallef IN, Stiff PJ, et al. Plerixafor plus granulocyte colonystimulating factor versus placebo plus granulocyte colonystimulating factor for mobilization of $\mathrm{CD} 34(+)$ hematopoietic stem cells in patients with multiple myeloma and low peripheral blood CD34(+) cell count: results of. Biol Blood Marrow Transpl. 2012;18:1564-72.

24. Li J, Hamilton E, Vaughn L, Graiser M, Renfroe H, Lechowicz MJ, et al. Effectiveness and cost analysis of "just-in-time" salvage plerixafor administration in autologous transplant patients with poor stem cell mobilization kinetics. Transfusion. 2011;51:2175-82.

25. Abusin GA, Abu-Arja RF, Gingrich RD, Silverman MD, Zamba GKD, Schlueter AJ. An algorithm for utilizing peripheral blood CD34 count as a predictor of the need for plerixafor in autologous stem cell mobilization--cost-effectiveness analysis. J Clin Apher. 2013;28:293-300.

26. Martin A, Richards S, Haycox A, Houten R, McLeod C, Braithwaite B, et al. Evaluating the use of plerixafor in stem cell mobilisation-an economic analysis of the PHANTASTIC trial. J Clin Apher. 2016;31:434-42.

27. Vishnu P, Roy V, Paulsen A, Zubair AC. Efficacy and cost-benefit analysis of risk-adaptive use of plerixafor for autologous hematopoietic progenitor cell mobilization. Transfusion. 2012;52:55-62.

28. Kim SS, Renteria AS, Steinberg A, Banoff K, Isola L. Pharmacoeconomic impact of up-front use of plerixafor for autologous stem cell mobilization in patients with multiple myeloma. Cytotherapy. 2014;16:1584-9.

29. Varmavuo V, Rimpiläinen J, Kuitunen H, Nihtinen A, Vasala K, Mikkola M, et al. Engraftment and outcome after autologous stem cell transplantation in plerixafor-mobilized non-Hodgkin's lymphoma patients. Transfusion. 2014;54:1243-50.

30. Mishra V, Andresen S, Brinch L, Kvaløy S, Ernst P, Lønset MK, et al. Cost of autologous peripheral blood stem cell transplantation: the Norwegian experience from a multicenter cost study. Bone Marrow Transpl. 2005;35:1149-53.

31. Tarella C, Di Nicola M, Caracciolo D, Zallio F, Cuttica A, Omedè $\mathrm{P}$, et al. High-dose ara-C with autologous peripheral blood progenitor cell support induces a marked progenitor cell mobilization: an indication for patients at risk for low mobilization. Bone Marrow Transpl. 2002;30:725-32. 